\title{
PV with Boost Converter Integrated Three-Level Inverter Fed PMSM Drive for Agricultural Application
}

\section{J. A. Ganeswari, R. Kiranmayi}

\begin{abstract}
Apprehension of inverter fed electric motors is made possible with the trends in power electronic technology. Permanent magnet synchronous motor (PMSM) is one motor replaced conventional electric motors with attractive features like compactness, lightweight and efficiency. This paper presents a $P V$ (Photo-voltaic) fed PMSM drive system for water pumping application. Photo-voltaic system is one among the renewable sources available free from atmosphere which can generate electricity with ease. Output of $P V$ is fed to a boost converter to generate required level of voltage to PMSM. Boost output is fed to a driving inverter to PMSM. Closed-loop boost converter feeding PMSM drive is analyzed. PMSM drive is a closed-loop system design to run at commanded speed. PV fed PMSM drive is validated with fixed speed and variable speed conditions.
\end{abstract}

Index Terms: PV, PMSM Drive, Boost, Inverter, Closed Loop Controller.

\section{INTRODUCTION}

With the latest growth in power electronic technology, conception of motor drives [1-3] is achieved replacing conventional motors. Motor drive technology is revolutionary making human efforts easier. Brushless DC (BLDC) motors and PMSM are among them. The mentioned motors, having sophisticated design trends the motor drive applications in many industries and commercial purpose. PMSM motor having rotating permanent magnet, with fixed and equally spaced windings. The magnetic flux produced by all the field windings is additive, but the field direction and magnitude can be altered by controlling the stator currents. Due to the interaction between net stator field and rotor torque is produced.

The PMSM works similar to that of synchronous motor but the rotor consists of permanent magnets in PMSM [4-6]. Stator windings of PMSM are distributed and the back EMF (BEMF) is sinusoidal in shape [7-9]. As the flux distribution is sinusoidal in the air gap making the BEMF a sinusoidal shape. PMSM motors are generally fed from sinusoidal source. If PMSM is to be fed from a DC source, inverter does the job of supplying sinusoidal excitation to phase windings of PMSM.

Renewable energy sources (RES) are trending in electrical technology due to their viable advantages. The major breakthrough from RES is that their ability to produce

Revised Manuscript Received on July 22, 2019.

J. A. Ganeswari, Ph.D. Scholar EEE Department, JNTUA, Anantapuramu, India

Dr. R. Kiranmayi, Professor \& HOD EEE Department, JNTUA, Anantapuramu, India sanitized electrical energy. This feature from RES has demanded to adopt renewable energy sources than conventional fossil fuel power generation. As the output voltage from a solar PV is low which is not sufficient to drive the system, hence there is a need for voltage boosting. Design of boost converter is depicted for both in open closed loop configuration and further closed-loop boost converter feeding PMSM drive is analyzed. PMSM drive is a closed-loop system design to run at commanded speed. PV fed PMSM drive is validated with fixed speed and variable speed conditions. This paper organized as follows, Section II explains PV system. Section III explains the Boost Converter modeling and with closed loop. IV describes the PV-Boost system for PMSM drive operation. Section 5 presents computer simulations. Section 6 presents conclusion Section 7 References.

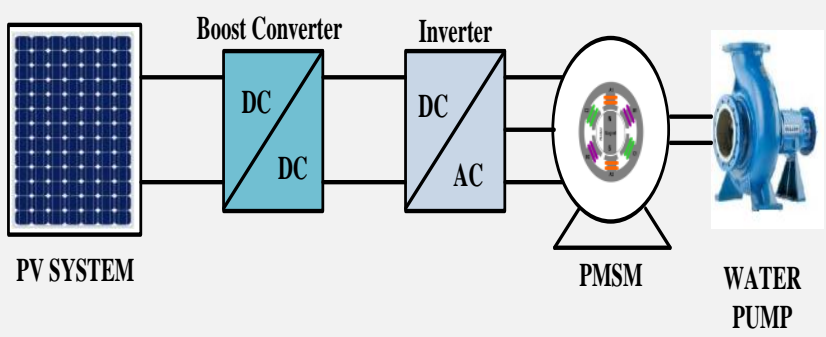

Figure 1: PV system integrated with Boost converter fed PMSM for agricultural water pumping application

\section{PHOTO-VOLTAIC (PV) SYSTEM}

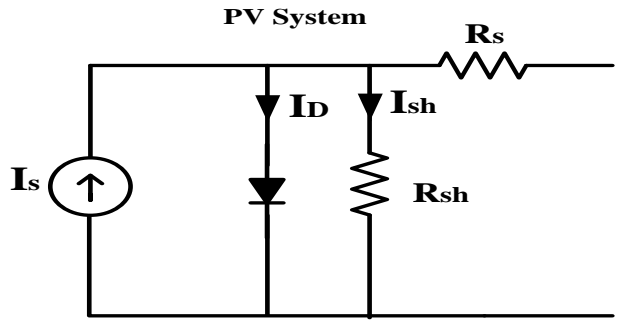

Figure 2. Equivalent circuit of PV cell

The continuously improving technologies have made the solar energy having potential to fulfill power needs in our daily lives. The flexibility in shape and size of Solar systems have made them more popular in recent trends [10-13]. Some of residential systems in India and most of them are found on rooftops across the United States. Most of the businesses communities are also preparing to install solar panels for to fulfill their power needs and thus reducing their cost of energy. Equivalent circuit 
consists of a current source representing the flow of electrons when electrons are energized by absorbing photon energy. Equivalent circuit also consists of parallel diode with series resistor and a parallel resistor. Therefore the net current supplied by the solar cell is the remaining load current which is being supplied a part to the diode and the quantity which is being wasted in the shunt resistor[10-11].

$$
I_{s}=I_{L}-I_{D}-I_{s h}
$$

Where, $I_{\mathrm{s}}$ is output current,

$\mathrm{I}_{\mathrm{L}}$ : Photo-generated current,

$\mathrm{I}_{\mathrm{D}}$ : Diode current, and

$\mathrm{I}_{\mathrm{SH}}:$ Shunt current.

The current through diode can be written as :

$$
I_{D}=I_{0}\left\{e^{\left[V_{j} / n k T / q\right]}-1\right\}
$$

Where, $I_{0}$ is reverse saturation current,

$\mathrm{n}$ : Diode ideality factor,

$\mathrm{q}$ : Charge, $\mathrm{k}$ is Boltzmann's constant

$\mathrm{T}$ : Absolute temperature

substituting all equations, characteristic equation of solar cell can be written as (3)

$$
I=I_{L}-I_{0}\left\{e^{\left[V_{j} / n k T / q\right]}-1\right\}-\frac{V+I R_{S}}{R_{S H}}
$$

\section{BOOST CONVERTER}

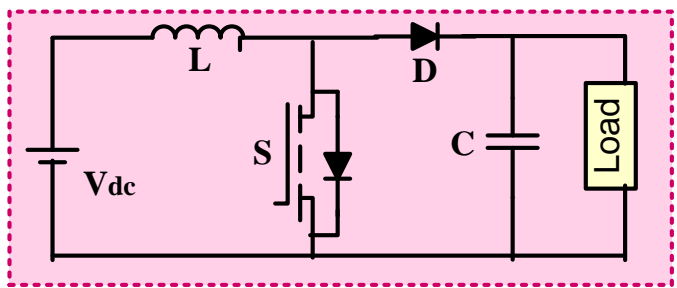

Figure 3: Boost Converter

\section{A. Modeling of Boost Converter}

Input voltage $\left(\mathrm{V}_{\mathrm{in}}\right)=200 \mathrm{~V}$, Output Voltage $\mathrm{V}_{\mathrm{O}}=800 \mathrm{~V}$

Output power $\left(\mathrm{P}_{\mathrm{O}}\right)=10 \mathrm{~kW}$, Frequency $\mathrm{F}=50 \mathrm{kHz}$

Ripple current $\Delta \mathrm{I}=5 \%$ of $\mathrm{I}_{\text {in }}$

Ripple voltage $\Delta V_{C}=2 \%$ of Output voltage

$\mathrm{O} / \mathrm{P}$ current $\mathrm{I}_{\mathrm{O}}=\frac{P}{V_{O}}=12.5 \mathrm{Amps}$

$$
\begin{array}{r}
\mathrm{O} / \mathrm{P} \text { resistance } \mathrm{R}=\frac{V_{O}}{I_{O}}=64 \Omega \\
\text { For Duty cycle, } \frac{V_{O}}{V_{\text {in }}}=\frac{1}{1-D}
\end{array}
$$

$\therefore$ Duty ratio $\mathrm{D}=0.75$

$$
\mathrm{I}_{\text {in }}=\frac{\mathrm{I}_{0}}{1-D}=50 \mathrm{~A}
$$

Inductor Ripple current $\Delta \mathrm{I}=5 \%$ of $\mathrm{I}_{\text {in }}$

$\Delta \mathrm{I}=2.5$ Amps

Ripple voltage $\Delta \mathrm{V}_{\mathrm{C}}=2 \%$ of Output voltage

$\Delta \mathrm{V}_{\mathrm{C}}=16$ volts

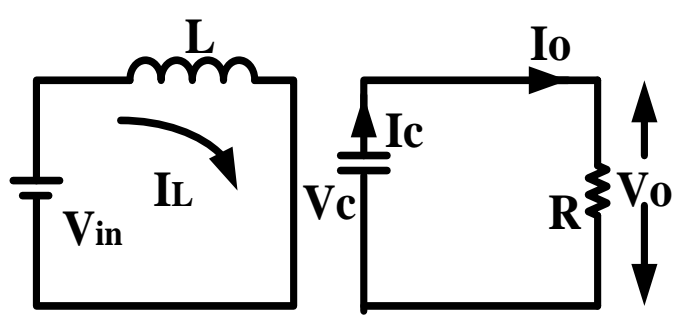

Figure 4: Boost Converter, in 'ON' condition

Figure 5 shows the basic boost converter circuit. When Switch in ON position, the inductor gets charged by source voltage and across the switch $\mathrm{S}$ as shown in figure 6 [14].

We have

$$
\begin{aligned}
\frac{V_{i n \times D}}{f \times L} \\
\mathrm{~L}=\frac{V_{i n} \times D}{f \times \Delta \mathrm{I}} \\
\therefore \mathrm{L}=1.2 \mathrm{mH} \\
\quad \text { Let } \mathrm{I}_{0}=\mathrm{I}_{\mathrm{C}}=\frac{V_{O}}{R}=\frac{\mathrm{C}_{\mathrm{d}} \Delta \mathrm{V}_{\mathrm{C}}}{d t} \\
\therefore \mathrm{C}=11.72 \mu \mathrm{F}
\end{aligned}
$$

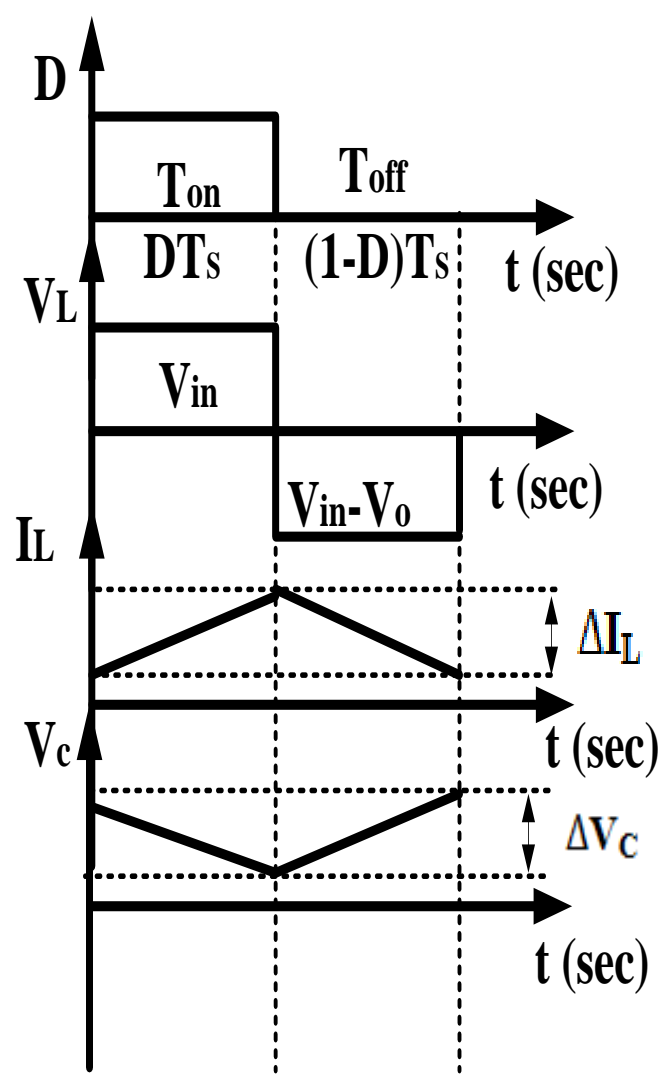

Figure 5 Timing diagram of boost converter. 
Table-1: Boost Converter design parameters

\begin{tabular}{|c|c|}
\hline Parameter & Value \\
\hline Input Voltage, $\mathrm{V}_{\text {in }}$ & $200 \mathrm{~V}$ \\
\hline Output Voltage, $\mathrm{V}_{0}$ & $800 \mathrm{~V}$ \\
\hline Power, $\mathrm{P}$ & $10 \mathrm{KW}$ \\
\hline $\begin{array}{c}\text { Switching } \\
\text { Frequency, } \mathrm{F}_{\mathrm{S}}\end{array}$ & $50 \mathrm{KHz}$ \\
\hline $\begin{array}{c}\text { Inductor Current } \\
\text { ripple, } \Delta \mathrm{I}_{\mathrm{L}}\end{array}$ & $2.5 \mathrm{~A}$ \\
\hline $\begin{array}{c}\text { Capacitor } \mathrm{V}_{\mathrm{O}} \text { ltage } \\
\text { ripple, } \Delta \mathrm{V}_{\mathrm{C}}\end{array}$ & $16 \mathrm{~V}$ \\
\hline Inductor, $\mathrm{L}$ & $1.2 \mathrm{mH}$ \\
\hline Capacitor, $\mathrm{C}$ & $11.72 \mu \mathrm{F}$ \\
\hline
\end{tabular}

B. Closed-Loop Boost Converter

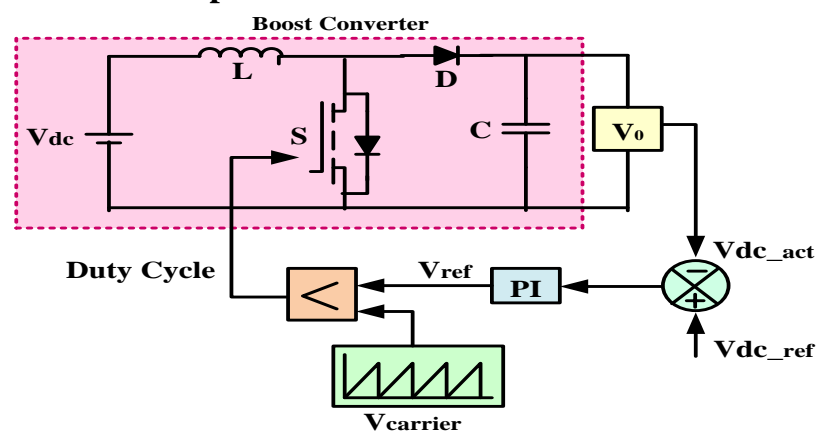

Figure 6. Closed-Loop Boost Converter

Figure 6 shows the closed-loop mode of operation boost converter. The output voltage is fed back through a controller in closed-loop operation to obtain stable and constant DC output from boost converter. The actual output voltage is sensed across output capacitor of boost converter and is compared to reference DC voltage. The error of DC voltage is fed to PI controller where it produces reference voltage signal. The reference voltage is compared with the carrier signal in the comparator and pulses produced from the comparator output will help the boost converter to enter into conduction mode which produces pulses to switch on boost converter. This operating phenomenon will result in constant output voltage with less ripple content.

\section{THREE-LEVEL VSI FED PMSM DRIVE}

PMSM is a synchronous motor consisting of only permanent magnets on its rotor and windings on its stator. Figure 7 shows the PMSM driven with inverter. PMSM is a synchronous motor and requires $\mathrm{AC}$ supply for its stator windings for motoring action. A DC source connected to the system is now to be inverted to AC through an inverter. Inverter consists of power electronic switches and the alternating output from the inverter energizes the phase windings of PMSM.

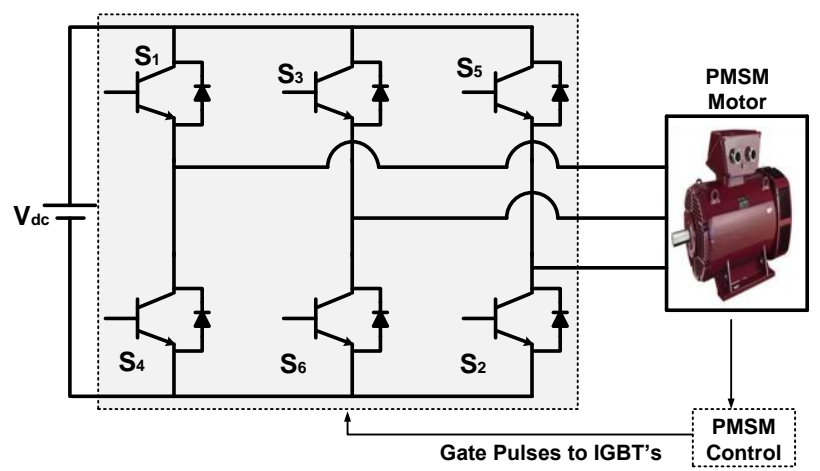

Figure 7: Inverter fed PMSM drive

As the output voltage from a solar PV is low which is not sufficient to drive the system, hence there is a need for voltage boosting. The complete schematic arrangement of PV integrated boost converter fed PMSM drive is depicted in figure 7. The low voltage output from PV system is fed to boost converter for boosting the voltage required to feed PMSM drive for water pumping application. The closed-loop mode DC-DC converter gives precise output. The boosted output from DC-DC boost converter is fed to inverter to convert the DC kind of supply to AC, as PMSM machine accepts AC type of excitation for field production. The inverter output of $\mathrm{AC}$ excitation excites the phase windings of PMSM machine which is coupled to a pump for water pumping application.

PMSM drive is controlled by controlling voltage source inverter. The VOC scheme is adopted for VSI, in which the three phase currents are sensed by two Hall effect current sensors are used to sense Ia, Ib and third phase source current to PMSM Ic are estimated considering sum of all the phase currents is zero. Reference motor speed $\left(\omega^{*}\right)$ is compared to actual motor speed. PI controller is used to process the speed error, and from that the reference Iq component is extracted. Reference Id and Iq components are converted to 'abc' frame using dq-abc transformation. The output of dq-abc yields reference three phases of currents and are compared to actual currents sensed from line. The errors in currents are fed to PWM controller to produce triggering command to six switches of inverter circuit[1-5].

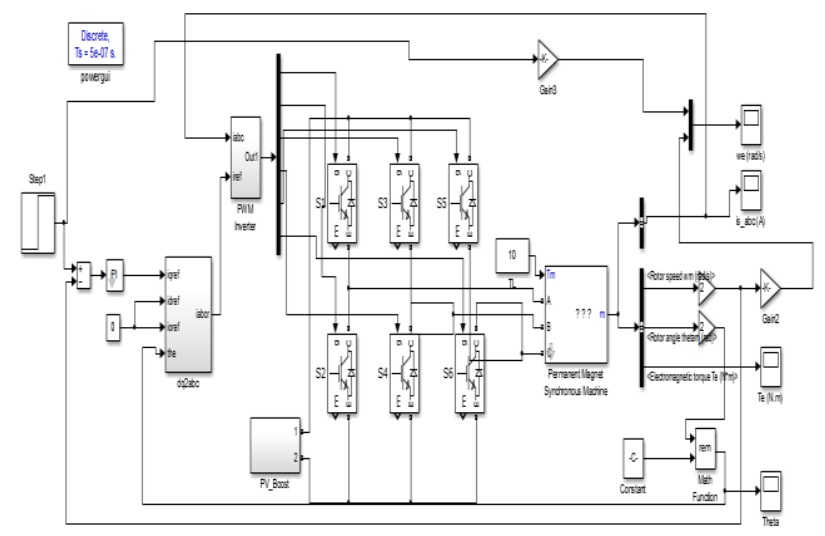

Figure 8: PV with Boost fed PMSM Drive 


\section{SIMULATION RESULTS}

A. Open-Loop Boost Converter

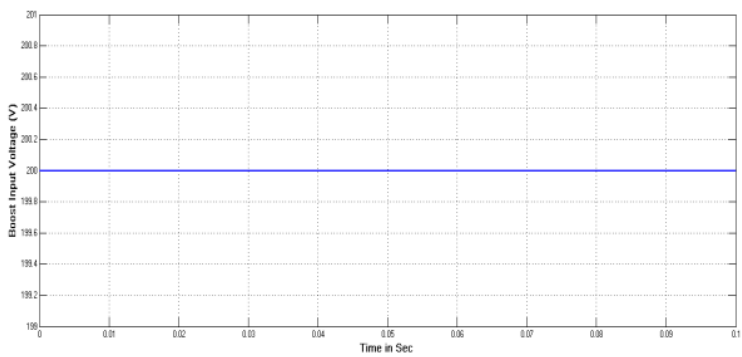

Figure 9: Boost converter input voltage at 200V

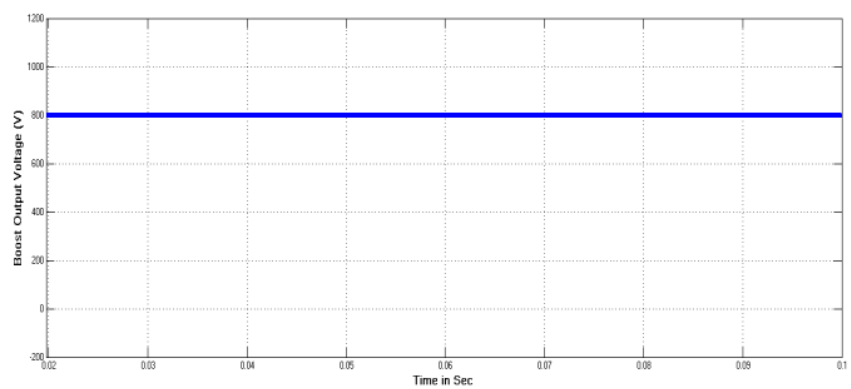

Figure 10: Boost converter output voltage boosted to 800V

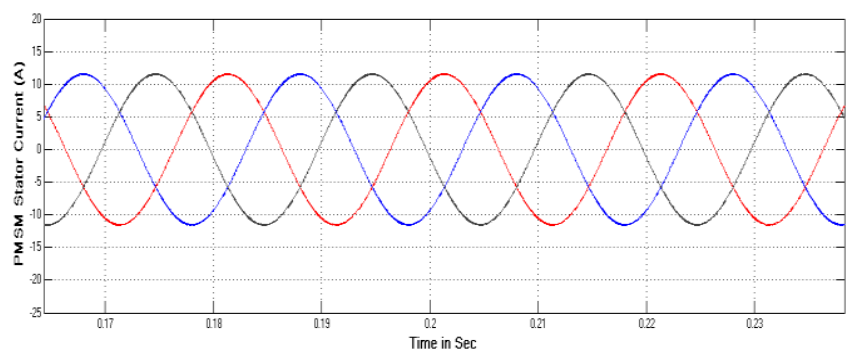

Figure11: Three-phase Stator currents of PMSM with constant peak of $12.5 \mathrm{~A}$.

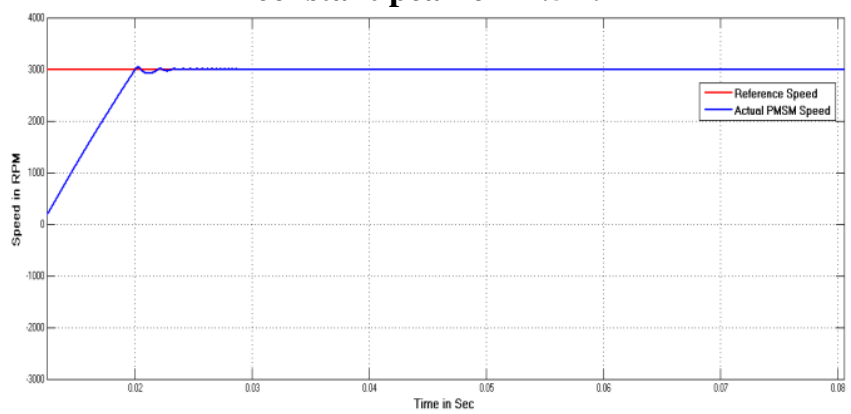

Figure 12: Speed of PMSM with reference speed command of 3000RPM is set in closed-loop

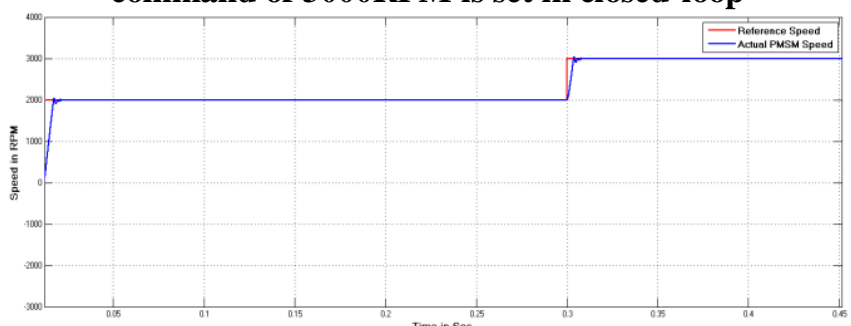

Fig 13: Variable Speed of PMSM at reference speed command of 2000RPM is set in closed-loop drive operation initially. At 0.3 seconds, set speed is varied to run PMSM at 3000RPM.

\section{CONCLUSION}

PMSM drives are becoming very good option for industrial and agricultural applications these days. This paper presents a PV fed PMSM drive system for water pumping application. PV system is integrated with conventional boost converter to produce high voltage output. Design calculations of boost converter parameters are explained and tabulated. Open-loop boost converter characteristics are illustrated. Closed-loop boost converter fed PMSM drive running at fixed speed and closed-loop boost converter fed PMSM drive running with variable speed command conditions are validated with the proposed system. DC output from boost converter is transformed to $\mathrm{AC}$ kind using conventional inverter to excite PMSM stator windings. The proposed system works satisfactorily for all conditions. PMSM drive responds to change in speeds with constant or variable irradiance which is proved from result analysis.

\section{REFERENCES}

1. R. Krishnan, "Permanent Magnet Synchronous and Brushless DC Motor Drives," CRC Press, Taylor and Francis Group. ISBN-978-0-8247-53849

2. Paul C.Krause, Oleg Wasynczuk, Scott D.Sundhoff, "Analysis of Electric Machinery and Drive Systems," IEEE Press Power Engineering society ISBN-0-471-14326-X

3. H,Madadi Kojabad, G.Ahrabian, "Simulation and analysis of the interior permanent magnet synchronous motor as a brushless AC-drive," Science direct / Simulation practice and theory 7(2000) 691-707

4. Pragasan Pillay, R.Krishnan." Modeling of Permanent Magnet Motor Drives", IEEE vol.35,no.4,november 1988

5. R. Dhaouadi, N. Mohan and L. Norum, "Design and implementation of an extended Kalman filter for the state estimation of a permanent magnet synchronous motor," IEEE Trans. Industrial Electronics, vol. 6. Jul. 1991, pp.491- 497.

6. K. Rajashekara, A. Kawamura and K. Matsuse, "Sensorless control of AC motor drives", New York: IEEE Press, 1996.

7. G. Sree Lakshmi, S. Kamakshaiah and T. R. Das, "Closed loop PI control of PMSM for hybrid electric vehicle using three level diode clamped inverter for optimal efficiency," Energy Efficient Technologies for Sustainability (ICEETS), 2013 International Conference on, Nagercoil, 2013, pp. 754-759.

8. H. H. Lee and U. H. Jeong "A Study on Speed Synchronization for Multi Motors using Controller Area Network" IEEE Trans. Ind. Appl., vol. 44 no. 42000

9. L. Feng Y. Koren and J. Borenstein "Cross-Coupling Motion Controller for Mobile Robots" IEEE Trans. on Control Systems Technology, vol. 1 December 1993.

10. D. Noel, F. Sozinho, D. Wilson and K. Hatipoglu, "Analysis of large scale photovoltaic power system integration into the existing utility grid using PSAT," SoutheastCon 2016, Norfolk, VA, 2016, pp. 1-7.

11. M. Ouada M. S. Meridjet N. Talbi "Optimization photovoltaic pumping system based BLDC using fuzzy logic MPPT control" Proc. Int. Renew. Sustain. Energy Conf. (IRSEC) pp. 27-31 Mar. 2013.

12. Terki A. Moussi A. Betka N. Terki "An improved efficiency of fuzzy logic control of PMBLDC for PV pumping system" Appl. Math. Model. vol. 36 no. 3 pp. 934-944 Mar. 2012.

13. Anurag, N. Deshmukh, A. Maguluri and S. Anand, "Integrated DC-DC Converter Based Grid-Connected Transformerless Photovoltaic Inverter with Extended Input Voltage Range," in IEEE Transactions on Power Electronics, vol. PP, no. 99, pp. 1-1.

14. J. A. Ganeswari, Dr. R. Kiranmayi, 'Performance Improvement for DC Boost Converter with Fuzzy Controller, 2nd International Conference on Inventive Systems and Control (ICISC 2018). 